\title{
Spatial distribution, association patterns and richness of tree species in a seasonal forest from the Serra Geral formation, southern Brazil
}

Rafael Barbizan Sühs ${ }^{1,2}$ and Jean Carlos Budke ${ }^{1}$

Recebido em 22/11/2010. Aceito em 15/06/2011

RESUMO

(Distribuição, associação espacial e riqueza de espécies arbóreas em uma floresta decídua da formação Serra Geral, sul do Brasil). Este estudo objetivou determinar a distribuição espacial das espécies arbóreas mais abundantes num remanescente florestal e avaliar relações que possam ser responsáveis por estas distribuições, bem como comparar a riqueza específica esperada ao longo da formação Serra Geral no estado do Rio Grande do Sul, Brasil. Uma parcela de 1 hectare, subdividida em 100 unidades amostrais contíguas foi instalada e todos os indivíduos com pelo menos $4,8 \mathrm{~cm}$ de diâmetro à altura do peito foram medidos e identificados. Cada unidade amostral recebeu uma descrição de sua posição espacial por meio de coordenadas $(\mathrm{x}, \mathrm{y})$ para quantificar o padrão espacial e posteriormente aplicar um índice de associação para as espécies amostradas. A riqueza específica foi comparada a outros levantamentos realizados na região da encosta da Serra Geral do estado do Rio Grande do Sul por meio de rarefação. Foram amostrados 1.063 indivíduos distribuídos em 69 espécies e 33 famílias. A diversidade especifica foi de 3,35 nats (equitatividade Pielou $\left.J^{\prime}=0,79\right)$ e a maioria das espécies apresentou distribuição agregada. Padrões de associação e dissociação foram encontrados entre as espécies, demonstrando diferentes grupos florestais. Foi observado que existe um decréscimo de espécies Atlânticas no sentido leste para oeste na formação Serra Geral, sendo substituídas por espécies da floresta estacional.

Palavras-chave: Rarefação; métricas de diversidade; associação espacial; agregação

\begin{abstract}
(Spatial distribution and association patterns of tree species in a seasonal forest from the Serra Geral formation, southern Brazil). This study aimed to determine the spatial distribution of the most abundant tree species, to look for relationships that may be responsible for their distribution and to compare the expected richness along the Serra Geral formation in the state of Rio Grande do Sul, Brazil. An one-hectare plot was divided in 100 contiguous $10 \mathrm{x}$ $10 \mathrm{~m}$ sampling units and all individuals with at least $4.8 \mathrm{~cm}$ diameter at breast high were measured and identified. Each sampling unit received a description of the spatial position through metric coordinates $(x, y)$ in order to quantify the spatial pattern. Later, an association index among species was applied. The observed richness was rarefied and compared to other surveys located on the slopes of Serra Geral in Rio Grande do Sul. We surveyed 1,063 individuals belonging to 69 species and 33 families, and the Shannon's diversity index showed a diversity of 3.35 nats (Pielou's species evenness - J' $=0.79$ ). Most species showed an aggregated distribution. Both association and dissociation patterns occurred among species leading to distinct forest patches. The rarefaction results showed a decrease of Atlantic species, which were replaced by typical seasonal forest species, when analyzing floristic contingents towards the west.
\end{abstract}

Key words: Rarefaction; diversity metrics; spatial association; aggregation

\section{Introduction}

In nature, organisms frequently show an aggregated distribution, forming patches, gradients or other types of spatial patterns (Legendre \& Fortin 1989; Dale et al. 2002). The analysis of such patterns is a relevant statistical tool in the area of forest dynamics (Pélissier 1998; Franklin \& Rey 2007), which helps in understanding species ecology and providing information for its management and conservation (Perry et al. 2002; Bell et al. 2010). In Brazil, studies about spatial distribution of plants were scarce in the last decade (Nascimento et al. 2002) but have started to increase in recent years (e.g. Anjos et al. 2004; Lindenmaier \& Budke 2006; Giehl et al. 2007; Paludo et al. 2009; Higuchi et al.2010; Rode et al.2010).

Due to advances in computational techniques in the past few decades (Perry et al. 2002; Hooten et al. 2003), several

\footnotetext{
1 Universidade Regional Integrada do Alto Uruguai e das Missões, Laboratório de Sistemática e Ecologia Vegetal, Departamento de Ciências Biológicas, Erechim, RS, Brazil

2 Author for correspondence: rbsuhs@gmail.com
} 
models have been created for the analysis of spatial patterns. In this sense, Dale et al. (2002) and Perry et al. (2002) described concepts and provided a broad framework for making decisions on analytical approaches and interpretations of spatial patterns. Among these methods, the Spatial Analysis by Distance Indices or SADIE, proposed by Perry (1995), has been successfully used in recent studies (Ferguson $e t$ al. 2000; Winder et al. 2001; Xu \& Madden 2004; Lindenmaier \& Budke 2006; Giehl et al. 2007; Rechenmacher et al. 2007), and has been useful in describing and quantifying spatial patterns (Xu 2003).

Based on the spatial pattern provided by SADIE, Perry \& Dixon (2002) created a new method of association analysis. By identifying the spatial heterogeneity as a patch or a gap, this method is more efficient in detecting associations than a simple correlation co-efficient (Donovan et al. 2007; Bell et al. 2010). Through the analysis of spatial pattern and association, Donovan et al. (2007) emphasized the importance of termites in a tropical forest in Malaysia. Bell et al. (2010) built co-occurrence networks based on statistical analysis of the SADIE method, providing valuable information on the area of biological control in the United Kingdom. Gabriel et al. (2007), using SADIE's method, verified that the young individuals of Cupania vernalis Cambess. do not follow the distribution of adults in a forest remnant in southern Brazil.

The state of Rio Grande do Sul (southern Brazil) has, beyond areas of sandbanks and pioneer formations, humid and seasonal forests (Teixeira et al. 1986). Nowadays the best preserved areas are located on the slopes, along the Serra Geral and Serra do Sudeste formations, mainly in inaccessible areas (Jarenkow \& Waechter 2001; Jurinitz \& Jarenkow 2003).

The main entrance corridors of tropical species in this state occur in the east, through the Atlantic Corridor, and in the west, across the basins of the Paraná and Uruguay rivers (Rambo 1956; 1961). Species interpenetration occurs on the hillside areas of Serra Geral (Jarenkow \& Waechter 2001). Rambo (1956; 1960) mentioned that as species move, from east to west, across the Serra Geral, there is a reduction trend in species richness, which is higher in Atlantic Forest stricto sensu and gradually becomes lower towards the seasonal forest. However, little has been discussed about this in recent years. Regardless of several structural studies about plant communities of the Serra Geral formation (Jarenkow 1994; Longhi et al. 1999; Longhi et al. 2000; Jarenkow \& Waechter 2001; Lindenmaier \& Budke 2006; Giehl et al. 2007; Sühs et al. 2010), the lack of standardized data, which occurs in most descriptive studies of terrestrial plant communities conducted in Brazil, makes it harder to compare their results (Sonego et al. 2007; Giehl \& Budke 2011).

This study aimed to determine the spatial distribution of the most abundant tree species from a seasonal forest remnant in the central region of Rio Grande do Sul, Brazil, and to look for relationships that may be responsible for their distribution. Likewise, the horizontal structure, di- versity and changes in species richness along the slopes of the Serra Geral region were also evaluated. In this sense, we tried to answer the following questions: i) how is the spatial pattern of the most abundant species sampled? ii) is there an association between the spatial distribution of these species? iii) is there reduction in the species richness, from east to west, along the Serra Geral formation?

\section{Materials and methods}

\section{Study area}

The study was conducted at Sinimbu, in the central region of Rio Grande do Sul State, Brazil, in a Private Reserve of Natural Heritage which belongs to the University of Santa Cruz do Sul. This reserve was officially created in 2009 (Brasil 2009) and has an area of 221.39 ha. Sühs et al. (2010) found 160 tree species in this area and observed that 12 are at risk of extinction. On the other hand, the same authors also found 11 exotic species and emphasized that these species must be controlled, especially the invasive ones.

According to Maluf (2000), the regional climate belongs to type STSBv, (subtropical, sub humid, with dry periods in summer). The average annual temperature is $19.3^{\circ} \mathrm{C}$ and average annual rainfall is $1,547 \mathrm{~mm}$, recorded in Santa Cruz do Sul, the nearest station (data supplied by the Laboratory of Meteorology, University of Santa Cruz do Sul). The local soils belong to an association of Ciríaco and Charrua mapping units (Streck et al. 2002).

\section{Data collection}

A plot of 1 hectare $(100 \times 100 \mathrm{~m})$ was set in the reserve domain and divided in 100 contiguous $10 \times 10 \mathrm{~m}$ sampling units (central point near coordinates $29^{\circ} 23^{\prime} 22^{\prime \prime} \mathrm{S}-52^{\circ} 32^{\prime} 00^{\prime \prime} \mathrm{W}$ at 500 m.s.l. - map available in Sühs et al. (2010). The plot was set on a slope, because it had better forest, where we observed the presence of two non-rectilinear gullies along the sampling area. All individuals with diameter at breast height $>4.8 \mathrm{~cm}$ were measured and identified. Voucher specimens were deposited in the HCB Herbarium at the University of Santa Cruz do Sul. Specimens were identified through literature and by comparison with vouchers from the HCB Herbarium. The classification of families of angiosperms was defined according to the Angiosperm Phylogeny Group (APGIII 2009) while Smith et al. (2006) was used to classify tree-like ferns. The nomenclature of species was based on Forzza et al. (2010).

The species were classified according to their floristic contingents: western seasonal (basins of Paraná and Uruguay rivers), eastern wet (Atlantic contingent), wide geographical distribution, Araucaria forest and exotics (Jarenkow \& Budke 2009, Jarenkow \& Waechter 2001, Budke et al. 2004, Lindenmaier \& Budke 2006, Sühs et al. 2010). We also grouped species by vertical distribution and in ecological groups of regeneration: "pioneer" for species that show an entirely heliophilous life cycle, "light-demanding" 
and "shade tolerant" for those who tolerate some degree of shade (Budke et al. 2008). The species were divided into three height groups: small (average height $<8 \mathrm{~m}$ ); medium (average height $\geq 8 \mathrm{~m}<12 \mathrm{~m}$ ) and tall (average height $\geq 12$ $\mathrm{m})$. Estimated height values were given in Sühs et al. (2010).

Twelve samples of topsoil $(0-20 \mathrm{~cm}$ depth) were randomly collected in the area and formed a single composite sample that was taken for chemical and texture analysis. The results were interpreted according to Comissão de Química e Fertilidade do Solo - RS/SC (2004).

\section{Data analysis}

For each species, the phytosociological parameters of density, frequency and dominance (derived from tree basal area) (Mueller-Dombois \& Ellenberg 1974) were calculated to describe the tree community structure. A histogram was constructed (class interval determined statistically at $4.8 \mathrm{~cm}$ ) to express the diameter classes of individuals.

In order to answer the first question of our study, we applied the SADIE methodology to evaluate the spatial patterns of species (Perry 1995). Each sampling unit received a description of the spatial position through metric coordinates $(x, y)$, mapped from an initial established point. Species showing more than 20 ind.ha ${ }^{-1}$ had their spatial distribution analyzed through the index of aggregation - $\mathrm{I}_{\mathrm{a}}$ (Perry 1995). Values of $\mathrm{I}_{\mathrm{a}}>1$ indicates aggregation (patches), $\mathrm{I}_{\mathrm{a}}<1$ indicates regularity and $I_{a}=1$ suggests randomness (Perry et al. 1996; Perry 1998). Negative values of aggregation indicates that a species- $i$ does not occur in that position (gaps), providing further details on pattern analysis (Perry et al. 1999).

According to Perry (1998), the spatial pattern in a sampled population is quantified by SADIE by measuring the total effort (in terms of distance moved), which the individuals in the observed sample must expend to move to extreme arrangements, in order to keep individuals either at uniformly (regularly) or aggregated (patchy) intervals. By comparing counts of the observed spatial pattern with random needed rearrangements, the degree of non-randomness within a set of data can be quantified (Perry 1998). Once the sampling-unit counts are the same for each randomization, the original heterogeneity of the sampled data is preserved (Xu 2003). Finally, distribution maps were produced using the kriging technique from the index values generated for each cluster plot, in which the aggregation index of each species was interpolated along the sampling area. These analyses were performed with the SADIEshell program (Perry et al. 1996; Conrad et al. 2006).

We used SADIES's association index (Perry \& Dixon 2002) to assess the spatial association of all sampled individuals, species richness and among most abundant species in order to answer the second question of this study. This spatial association refers to the similarity between the spatial patterns of two data sets, and it was equivalent to a spatially explicit correlation coefficient that tests the level of association between two populations (Bell et al. 2010). According to Perry \& Dixon (2002), a positive association is expected when the spatial distributions of two species join both in patches and gaps. In addition, if the spatial distribution of patches and gaps do not coincide, a spatial dissociation is expected. The spatial associations were undertaken with the SADIEshell program (Perry et al. 1996; Conrad et al. 2006).

Rarefaction curves from the number of sampled individuals (Koellner et al. 2004) were created to compare species richness to other studies developed on the slopes of the Serra Geral region in Rio Grande do Sul, Brazil. By this methodology, the expected richness can be estimated in a random previously determined individual sample (Waite 2000). Following this, the results of other studies carried out in the slopes of the Serra Geral formation, in Rio Grande do Sul, were adapted for the construction of the rarefaction curves. In this way, a matrix of species abundance was built and, based on Forzza et al. (2010), the species names were updated and their synonymy was verified. The survey showing the lowest number of individuals was set as the basis for the comparison. Some studies were not included due to a low sampling effort or by omitting the names of species or grouping, which could weaken the comparison. Neophytes were excluded from this analysis but non-identified taxa or taxa identified at the level of family or genus were kept. Alpha ( $\alpha$ ) diversity was calculated through Shannon's diversity index with Pielou's evenness index (neophytes were excluded). Rarefaction and diversity analysis were performed within the PAST package (Hammer et al. 2001).

Spearman correlation coefficient $\left(r_{s}\right)$ was used to verify whether there was a reduction of species richness from east to west along Serra Geral formation. In order to answer the third question of this study we further partitioned the amount of species from each floristic contingent (western seasonal and eastern wet). Correlation analyses were performed with JMP ${ }^{\circledR}$ software (Version 9. SAS Institute Inc., Cary, NC, 1989-2007).

\section{Results}

\section{Soil}

The soil samples showed high proportion of silt and low proportions of clay and sand, leading to a soil class "four", which group soils with medium content of organic matter, base saturation and $\mathrm{pH}$. The cation exchange capacity (CEC) was considered high, in the same way as Calcium $(\mathrm{Ca})$, Magnesium (Mg) and Sulfur (S). Zinc (Zn), Boron (B) and Manganese (Mn) levels were considered high, while copper $(\mathrm{Cu})$ was considered medium. The Aluminum $(\mathrm{Al})$ saturation was null and base saturation had a high rate (Tab. 1).

\section{Structure}

This study surveyed 1,024 living trees belonging to 69 species and 33 families. The species with highest absolute densities were Casearia sylvestris, with 127 individuals (12.4\%), 
Table 1. Physical and chemical parameters obtained with soil samples collected in a seasonal forest in central region of Rio Grande do Sul state, Brazil.

\begin{tabular}{|c|c|}
\hline & Depth $(\mathrm{cm})$ \\
\hline Analysis & $0-20$ \\
\hline Sand (\%) & $21 \%$ \\
\hline Silt (\%) & $59 \%$ \\
\hline Clay (\%) & $20 \%$ \\
\hline $\mathrm{pH}$ & 5.6 \\
\hline $\mathrm{P}(\mathrm{mg} / \mathrm{L})$ & 7 \\
\hline $\mathrm{K}(\mathrm{mg} / \mathrm{L})$ & 296 \\
\hline O.M. (\%) & 4.9 \\
\hline $\mathrm{Al}\left(\mathrm{cmol}_{\mathrm{c}} / \mathrm{L}\right)$ & 0.0 \\
\hline $\mathrm{Ca}\left(\mathrm{cmol}_{\mathrm{c}} / \mathrm{L}\right)$ & 11.8 \\
\hline $\mathrm{Mg}\left(\mathrm{cmol}_{\mathrm{c}} / \mathrm{L}\right)$ & 2.9 \\
\hline $\mathrm{H}+\mathrm{Al}\left(\mathrm{cmol}_{\mathrm{c}} / \mathrm{L}\right)$ & 4.9 \\
\hline $\mathrm{CEC}\left(\mathrm{cmol}_{\mathrm{c}} / \mathrm{L}\right)$ & 20.4 \\
\hline $\mathrm{S}(\mathrm{mg} / \mathrm{L})$ & 16.5 \\
\hline $\mathrm{Zn}(\mathrm{mg} / \mathrm{L})$ & 14.5 \\
\hline $\mathrm{Cu}(\mathrm{mg} / \mathrm{L})$ & 0.2 \\
\hline B (mg/L) & 0.7 \\
\hline $\mathrm{Mn}(\mathrm{mg} / \mathrm{L})$ & 66 \\
\hline $\mathrm{Fe}(\%)$ & 0.13 \\
\hline Basis Saturation (\%) & 75.8 \\
\hline Al Saturation (\%) & 0.0 \\
\hline
\end{tabular}

Nectandra megapotamica, with 106 (10.3\%), Sorocea bonplandii, with 94 (9.2\%), Alchornea triplinervia, with 72 (7.0\%), Cupania vernalis, with 67 (6.5\%) and Allophylus edulis, with 51 (5.0\%). Together these species totaled $50.4 \%$ of surveyed individuals (Tab. 2). With respect to absolute frequency, a small number $(13 \%)$ of the sampled species occupied higher values of frequency classes (between $20 \%$ and $60 \%$ ), while $87 \%$ of sampled species had frequency classes between $0 \%$ and 20\%. Nectandra megapotamica was the most frequent $(\mathrm{AF}=59 \%)$. Regarding dominance, the overall basal area was $24.10 \mathrm{~m}^{2} \cdot \mathrm{ha}^{-1}$, where the highest values were recorded for $N$. megapotamica, which had $9.04 \mathrm{~m}^{2} \cdot \mathrm{ha}^{-1}$, A. triplinervia with $2.82 \mathrm{~m}^{2} \cdot \mathrm{ha}^{-1}$ and Tetrorchidium rubrivenium with 2.12 $\mathrm{m}^{2} \cdot \mathrm{ha}^{-1}$. Together these species account for $58 \%$ of the total value of dominance. Nectandra megapotamica held $37.5 \%$ of the total basal area, with several large sized individuals (height and diameter values above average). Casearia sylvestris and Sorocea bonplandii had high values of density and frequency and low values of dominance because they showed several well distributed small trees. On the other hand, Tetrorchidium rubrivenium and Ocotea puberula had higher values of dominance with lower values of frequency and density. Concerning the diameter, $50 \%$ of sampled individuals had diameters between 4.8 and $9.7 \mathrm{~cm}$ (Fig. 1).

\section{Spatial distribution and association patterns}

Twelve species showed absolute density higher than 20 individuals.ha ${ }^{-1}$ and had their spatial pattern analyzed (Fig. 2 and 3). All of them were aggregated ( $\mathrm{I}>1$ ), except Myrsine guianensis and Trichilia claussenii. Alchornea triplinervia, Cupania vernalis, Cabralea canjerana, Myrsine umbellata, Tetrorchidium rubrivenium and Diospyros inconstans had significant aggregation values (Tab. 4).

The spatial distributions of Alchornea triplinervia and Diospyros inconstans were significantly associated to the spatial distribution of species richness per sampling unit or, as the case of Cupania vernalis, showed a dissociated pattern between overall species richness and plant species abundance (Tab. 4). The spatial distributions of Casearia sylvestris, Alchornea triplinervia, Allophylus edulis, Myrsine umbellata and Tetrorchidium rubrivenium were significantly associated with the overall number of individuals (Tab. 4). Furthermore, we verified that some species were significantly associated $(p<0.025)$ with each other. On this way, regardless of their abundance, the spatial patterns (distribution) are similar both in areas of patches (high abundance) and in areas of gaps (low abundance). At the same time, some species showed significant dissociation $(p>0.975)$ with each other, indicating that the spatial patterns in both areas (patches and gaps) did not match. According to this, Tab. 5 shows the significant dissociation between Alchornea triplinervia and Cupania vernalis and, as expected, their associations with other species, which were frequently dissimilar; Diospyros inconstans showed significant association with $A$. triplinervia and significant dissociation with C. vernalis, while Myrsine guianensis showed significant association with $A$. triplinervia and a dissociation trend with $C$. vernalis. The same occurred between Sorocea bonplandii and Allophylus edulis. Both of these species showed a tendency to be dissociated with each other but $S$. bonplandii showed a trend to be associated to Cabralea canjerana, which also showed a dissociation trend with A. edulis. Finally, we observed that Casearia sylvestris was significantly associated to A. edulis and showed a trend to be dissociated to C. canjerana. Only C. vernalis did not show associations with any other species.

\section{Alpha Diversity and Species Richness}

The Shannon's diversity index $\left(\mathrm{H}^{\prime}\right)$ showed a diversity of 3.34 nats.ind with Pielou's evenness of J' $=0.79$. According to the rarefaction procedure, the survey located in the farthest eastern region (municipality of Morrinhos do Sul) showed the highest species richness ( 92 species), followed by Montenegro, also located in the east (66) and this study, in central region (66 species), then Santa Maria in the west (55) and Vale do Sol in the central region (48) (Tab. 3). The latter, although located a bit westward, had more characteristics from the eastern contingent than the present one, probably due to its elevation, justifying its ordinance before our survey in Tab. 3. We did not find a reduction of species richness from east to west $\left(r_{s}=-0.61 ; p=\right.$ 0.27). After partitioning the amount of species of eastern and western floristic contingents, we observed a trend of increasing 
Spatial distribution, association patterns and richness of tree species in a seasonal forest from the Serra Geral formation, southern Brazil

Table 2. Structural parameters of a seasonal forest in central region of Rio Grande do Sul state, Brazil, collected in 100 contiguous subplots of $10 \times 10 \mathrm{~m}^{2}$ each.

\begin{tabular}{|c|c|c|c|c|c|}
\hline Family/species & ADo & $\mathrm{AD}$ & $\mathrm{AF}$ & EG & PC \\
\hline SALICACEAE & 1.321 & 175 & 71 & & \\
\hline Banara parviflora (A.Gray) Benth. & 0.167 & 18 & 18 & LD-M & WDS \\
\hline Banara tomentosa Clos & 0.066 & 9 & 7 & LD-S & PUB \\
\hline Casearia decandra Jacq. & 0.033 & 5 & 5 & ST-M & PUB \\
\hline Casearia sylvestris $\mathrm{Sw}$. & 0.979 & 127 & 57 & LD-M & WDS \\
\hline Xylosma pseudosalzmannii Sleumer & 0.076 & 16 & 14 & ST-S & PUB \\
\hline LAURACEAE & 10.236 & 127 & 70 & & \\
\hline Aiouea saligna Meisn. & 0.114 & 6 & 6 & ST-M & ATL \\
\hline Nectandra lanceolata Nees & 0.051 & 2 & 2 & LD-M & PUB \\
\hline Nectandra megapotamica (Spreng.) Mez & 9.036 & 106 & 59 & LD-T & WDS \\
\hline Ocotea puberula (Rich.) Nees & 1.020 & 12 & 12 & LD-T & WDS \\
\hline Ocotea pulchella (Nees \& Mart.) Mez & 0.015 & 1 & 1 & LD-T & WDS \\
\hline EUPHORBIACEAE & 5.050 & 126 & 60 & & \\
\hline Actinostemon concolor (Spreng.) Müll.Arg. & 0.018 & 8 & 7 & ST-S & WDS \\
\hline Alchornea triplinervia (Spreng.) Müll.Arg. & 2.816 & 72 & 43 & LD-T & WDS \\
\hline Sapium glandulosum (L.) Morong & 0.004 & 1 & 1 & PI-M & WDS \\
\hline Sebastiania brasiliensis Spreng. & 0.003 & 1 & 1 & LD-S & WDS \\
\hline Sebastiania commersoniana (Baill.) L.B.Sm. \& Downs & 0.112 & 15 & 7 & PI-M & WDS \\
\hline Tetrorchidium rubrivenium Poepp. & 2.115 & 29 & 21 & LD-T & WDS \\
\hline SAPINDACEAE & 1.570 & 118 & 52 & & \\
\hline Allophylus edulis (A.St.-Hil. et al.) Hieron. ex Niederl. & 0.640 & 51 & 32 & LD-M & WDS \\
\hline Cupania vernalis Cambess. & 0.930 & 67 & 35 & LD-M & WDS \\
\hline MORACEAE & 0.562 & 104 & 59 & & \\
\hline Ficus luschnathiana (Miq.) Miq. & 0.295 & 10 & 9 & LD-T & WDS \\
\hline Sorocea bonplandii (Baill.) W.C.Burger et al. & 0.267 & 94 & 54 & ST-S & WDS \\
\hline MELIACEAE & 1.738 & 82 & 52 & & \\
\hline Cabralea canjerana (Vell.) Mart. & 0.873 & 40 & 34 & LD-M & WDS \\
\hline Cedrela fissilis Vell. & 0.739 & 16 & 16 & LD-T & WDS \\
\hline Trichilia clausseni C.DC. & 0.120 & 23 & 16 & LD-S & PUB \\
\hline Trichilia elegans A.Juss. & 0.006 & 3 & 3 & ST-S & PUB \\
\hline PRIMULACEAE & 1.060 & 80 & 45 & & \\
\hline Myrsine coriacea (Sw.) R.Br. ex Roem. \& Schult. & 0.056 & 1 & 1 & PI-T & WDS \\
\hline Myrsine guianensis (Aubl.) Kuntze & 0.511 & 46 & 34 & LD-M & WDS \\
\hline Myrsine umbellata Mart. & 0.493 & 33 & 20 & PI-M & WDS \\
\hline FABACEAE & 0.716 & 52 & 37 & & \\
\hline Albizia edwallii (Hoehne) Barneby \& J.W.Grimes & 0.060 & 2 & 2 & LD-T & PUB \\
\hline Dalbergia frutescens (Vell.) Britton & 0.011 & 3 & 3 & LD-M & PUB \\
\hline Enterolobium contortisiliquum (Vell.) Morong & 0.027 & 1 & 1 & LD-T & PUB \\
\hline Inga marginata Willd. & 0.010 & 1 & 1 & LD-M & WDS \\
\hline Inga vera Willd. & 0.070 & 3 & 3 & PI-T & PUB \\
\hline Lonchocarpus nitidus (Vogel) Benth. & 0.121 & 5 & 4 & LD-M & PUB \\
\hline Machaerium paraguariense Hassl. & 0.235 & 19 & 13 & LD-M & PUB \\
\hline Myrocarpus frondosus Allemão & 0.042 & 6 & 6 & LD-M & PUB \\
\hline Parapiptadenia rigida (Benth.) Brenan & 0.141 & 12 & 10 & LD-M & PUB \\
\hline
\end{tabular}


Table 2. Continuation.

\begin{tabular}{|c|c|c|c|c|c|}
\hline Family/species & ADo & $\mathrm{AD}$ & $\mathrm{AF}$ & EG & PC \\
\hline EBENACEAE & 0.148 & 21 & 16 & & \\
\hline Diospyros inconstans Jacq. & 0.148 & 21 & 16 & LD-S & PUB \\
\hline MONIMIACEAE & 0.099 & 20 & 17 & & \\
\hline Hennecartia omphalandra J.Poiss. & 0.056 & 5 & 5 & ST-S & PUB \\
\hline Mollinedia schottiana (Spreng.) Perkins & 0.043 & 15 & 12 & ST-S & ATL \\
\hline CUNONIACEAE & 0.431 & 14 & 11 & & \\
\hline Lamanonia ternata Vell. & 0.431 & 14 & 11 & LD-M & WDS \\
\hline MELASTOMATACEAE & 0.110 & 14 & 13 & & \\
\hline Miconia pusilliflora (DC.) Naudin & 0.110 & 14 & 13 & LD-M & WDS \\
\hline SAPOTACEAE & 0.111 & 13 & 10 & & \\
\hline Chrysophyllum gonocarpum (Mart. \& Eichler ex Miq.) Engl. & 0.040 & 3 & 3 & ST-M & PUB \\
\hline Chrysophyllum marginatum (Hook. \& Arn.) Radlk. & 0.071 & 10 & 8 & LD-M & PUB \\
\hline RUTACEAE & 0.069 & 11 & 10 & & \\
\hline Citrus X limon (L.) Osbeck & 0.003 & 1 & 1 & U-S & EXT \\
\hline Zanthoxylum caribaeum Lam. & 0.067 & 10 & 10 & LD-S & WDS \\
\hline BORAGINACEAE & 0.080 & 11 & 9 & & \\
\hline Cordia americana (L.) Gottschling \& J.S.Mill. & 0.003 & 1 & 1 & LD-S & PUB \\
\hline Cordia ecalyculata Vell. & 0.011 & 3 & 3 & ST-S & PUB \\
\hline Cordia trichotoma (Vell.) Arráb. ex Steud. & 0.066 & 7 & 7 & LD-M & WDS \\
\hline MALVACEAE & 0.102 & 9 & 8 & & \\
\hline Luehea divaricata Mart. \& Zucc. & 0.102 & 9 & 8 & PI-M & WDS \\
\hline MYRTACEAE & 0.032 & 6 & 6 & & \\
\hline Eugenia involucrata DC. & 0.006 & 2 & 2 & ST-S & PUB \\
\hline Eugenia rostrifolia D.Legrand & 0.021 & 2 & 2 & ST-S & PUB \\
\hline Eugenia uniflora $\mathrm{L}$. & 0.005 & 2 & 2 & LD-S & WDS \\
\hline CYATHEACEAE & 0.027 & 6 & 1 & & \\
\hline Alsophila setosa Kaulf. & 0.027 & 6 & 1 & ST-S & WDS \\
\hline ANNONACEAE & 0.025 & 5 & 5 & & \\
\hline Annona sylvatica A.St.-Hil. & 0.025 & 5 & 5 & LD-S & WDS \\
\hline NYCTAGINACEAE & 0.085 & 5 & 5 & & \\
\hline Pisonia ambigua Heimerl & 0.085 & 5 & 5 & LD-M & WDS \\
\hline SIMAROUBACEAE & 0.084 & 5 & 3 & & \\
\hline Picrasma crenata (Vell.) Engl. & 0.084 & 5 & 3 & LD-M & PUB \\
\hline LAMIACEAE & 0.023 & 3 & 2 & & \\
\hline Vitex megapotamica (Spreng.) Moldenke & 0.023 & 3 & 2 & LD-M & WDS \\
\hline RUBIACEAE & 0.012 & 3 & 3 & & \\
\hline Coutarea hexandra (Jacq.) K.Schum. & 0.009 & 2 & 2 & ST-M & PUB \\
\hline Randia armata (Sw.) DC. & 0.002 & 1 & 1 & ST-S & WDS \\
\hline ANACARDIACEAE & 0.079 & 2 & 2 & & \\
\hline Lithrea brasiliensis Marchand & 0.079 & 2 & 2 & LD-M & PUB \\
\hline PROTEACEAE & 0.013 & 2 & 2 & & \\
\hline Roupala montana var. brasiliensis (Klotzsch) K.S.Edwards & 0.013 & 2 & 2 & ST-M & ARA \\
\hline RHAMNACEAE & 0.074 & 2 & 2 & & \\
\hline Hovenia dulcis Thunb. & 0.074 & 2 & 2 & PI-M & EXT \\
\hline
\end{tabular}


Table 2. Continuation.

\begin{tabular}{|c|c|c|c|c|c|}
\hline Family/species & ADo & $\mathrm{AD}$ & $\mathrm{AF}$ & EG & PC \\
\hline URTICACEAE & 0.011 & 2 & 1 & & \\
\hline Urera baccifera (L.) Gaudich. ex Wedd. & 0.011 & 2 & 1 & LD-S & PUB \\
\hline ARALIACEAE & 0.068 & 1 & 1 & & \\
\hline Schefflera morototoni (Aubl.) Maguire et al. & 0.068 & 1 & 1 & LD-T & PUB \\
\hline BIGNONIACEAE & 0.022 & 1 & 1 & & \\
\hline Tecoma stans (L.) Juss. ex Kunth & 0.022 & 1 & 1 & PI-M & EXT \\
\hline CANNABACEAE & 0.006 & 1 & 1 & & \\
\hline Trema micrantha (L.) Blume & 0.006 & 1 & 1 & PI-S & WDS \\
\hline CARICACEAE & 0.028 & 1 & 1 & & \\
\hline Vasconcellea quercifolia A.St.-Hil. & 0.028 & 1 & 1 & LD-M & WDS \\
\hline ROSACEAE & 0.070 & 1 & 1 & & \\
\hline Prunus myrtifolia (L.) Urb. & 0.070 & 1 & 1 & LD-T & WDS \\
\hline SOLANACEAE & 0.017 & 1 & 1 & & \\
\hline Cestrum intermedium Sendtn. & 0.017 & 1 & 1 & LD-M & PUB \\
\hline
\end{tabular}

$\mathrm{ADo}=$ absolute dominance $\left(\mathrm{m}^{2} \cdot \mathrm{ha}^{-1}\right) ; \mathrm{AD}=$ absolute density (ind.ha $\left.{ }^{-1}\right) ; \mathrm{AF}=$ absolute frequency $(\%) ; \mathrm{EG}=$ ecological groups; $\mathrm{T}=$ tall; $\mathrm{M}=$ medium; $\mathrm{S}=$ small; $\mathrm{LD}=$ light-demanding; $\mathrm{ST}$ = shade-tolerant; $\mathrm{PI}=$ pioneer; $\mathrm{U}=$ undetermined; $\mathrm{PC}=$ phytogeographic characteristics; $\mathrm{WDS}=$ widely distributed species; $\mathrm{PUB}=$ species from basins of Paraná and Uruguay rivers; ATL = Atlantic contingent species; EXT = exotic species; ARA = species from Araucária forest; Table ranked in absolute density per family.

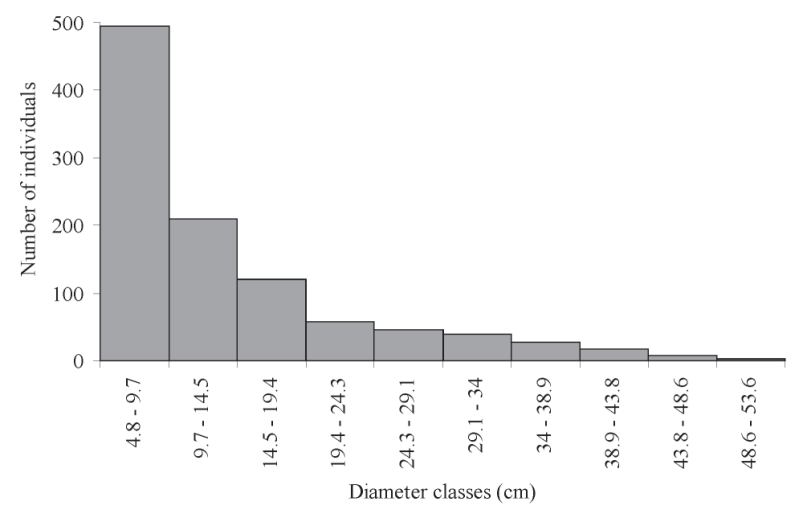

Figure 1. Distribution of tree individuals by diameter class (class interval of $4.8 \mathrm{~cm}$ ), obtained in a survey in a seasonal forest in the central region of Rio Grande do Sul State, Brazil.

species for the western seasonal species $\left(\mathrm{r}_{\mathrm{s}}=0.80 ; \mathrm{p}=0.10\right)$ from east to west and a trend of decreasing for the eastern wet species $\left(r_{s}=-0.90 ; p=0.03\right)$ in the same direction. There was no correlation between eastern wet and western seasonal $\left(\mathrm{r}_{\mathrm{s}}\right.$ $=-0.60 ; \mathrm{p}=0.28)$.

\section{Discussion}

$50 \%$ of the sampled individuals had a diameter between 4.8 and $9.7 \mathrm{~cm}$ (Fig. 1). This result highlights the importance of the understory and regenerating individuals in the community, while, if we had adopted a higher inclusion criterion (e.g. $10 \mathrm{~cm} \mathrm{DBH}$, as used in some studies in tropical and subtropical forests), we would have found only middle and upper layers and half of the surveyed individuals.

Spatial distribution and association patterns - Three species that showed aggregation in the present study also had aggregation in the study of Lindenmaier \& Budke (2006), located in Cachoeira do Sul, Rio Grande do Sul, in a riverine forest. Although they used a higher inclusion criterion, $\mathrm{Ca}$ searia sylvestris, Sorocea bonplandii and Cabralea canjerana showed significant values of aggregation in their survey, the latter had a significant value of aggregation in our study. This could indicate that these species present aggregation not only due to local factors but also as a natural behavior.

Most species showed significant or relatively high values of association or dissociation with other ones. In other words, all of them had some degree of association or dissociation, not occurring regularly in the horizontal space. The causes of such patterns are not well understood or studied, although credit has mainly focused on biotic and abiotic interactions. Nevertheless, some considerations can be made to understand part of these processes; if there is association between species, it indicates that they occupied the same areas (patches and gaps) in the survey. So we can infer that I) one of them is being (or has been) favored by the other (Levine, 1999; Brooker et al. 2008), which may indicate habitat changing in the way one or both species had been successfully established (facilitation); II) both are (or could have) benefiting from a third biotic or abiotic factor(s); III) 
Table 3. Data of surveys realized in the slope of Serra Geral formation, in Rio Grande do Sul state, Brazil, after the adaptation procedure (revision of synonyms, exclusion of neophytes), ordered from east to west.

\begin{tabular}{|c|c|c|c|c|c|c|c|c|c|c|}
\hline Local & $\mathrm{n}$ & area & $S$ & R1020 & $\mathrm{s}$ & A sp & B sp & E sp & $\mathrm{H}^{\prime}$ & $\mathrm{J}^{\prime}$ \\
\hline Morrinhos do Sul, RS ${ }^{1}$ & 2822 & 1.00 & 112 & 92 & 3.14 & 22.04 & 5.06 & 11.5 & 3.66 & 0.77 \\
\hline Montenegro, RS ${ }^{2}$ & 3514 & 1.83 & 78 & 66 & 2.36 & 4.93 & 3.77 & 13.0 & 3.06 & 0.70 \\
\hline Vale do Sol, RS ${ }^{3}$ & 1855 & 1.00 & 55 & 48 & 2.15 & 5.49 & 13.7 & 10.9 & 2.24 & 0.56 \\
\hline Sinimbu, RS ${ }^{4}$ & 1020 & 1.00 & 66 & 66 & 0.00 & 2.0 & 28.0 & 35.0 & 3.34 & 0.79 \\
\hline Santa Maria, RS ${ }^{5}$ & 1427 & 1.00 & 58 & 55 & 1.45 & 0.79 & 18.5 & 22.1 & 3.07 & 0.75 \\
\hline
\end{tabular}

$\mathrm{n}=$ number of individuals; area = survey area (hectare); $\mathrm{S}=$ species richness; $\mathrm{A} \mathrm{sp}=$ number of species from Atlantic contingent; $\mathrm{B} \mathrm{sp}=\mathrm{number}$ of $\mathrm{species}$ from basins of Paraná and Uruguay rivers; E sp = number of widely distributed species; R1020 = species richness acquired with rarefaction curves for 1020 individuals ( with standard deviation = s); H' = Shannon's diversity index; J' = Pielou's evenness index; ${ }^{1}$ Jarenkow (1994); ${ }^{2}$ Longhi et al. (2008); ${ }^{3}$ Jarenkow \& Waechter $(2001)$; ${ }^{4}$ This study; ${ }^{5}$ Giehl et al. (2007).

Table 4. Values obtained with index of aggregation and association for species with at least 20 individuals surveyed in a seasonal forest in central region of Rio Grande do Sul state, Brazil.

\begin{tabular}{|c|c|c|c|c|c|c|}
\hline Espécie & $\mathrm{N}$ & I a & Mvj & Mvi & Spi $x$ Spp & Spi $\mathrm{x}$ Nind \\
\hline Casearia sylvestris & 127 & 1.028 & -1.036 & 1.051 & 0.0315 & $<0.0001+$ \\
\hline Nectandra megapotamica & 106 & 1.050 & -1.039 & 1.049 & 0.7736 & 0.1228 \\
\hline Sorocea bonplandii & 94 & 1.109 & -1.109 & 1.030 & 0.0497 & 0.1722 \\
\hline Alchornea triplinervia & 72 & $1.676^{* * *}$ & $-1.669^{* * *}$ & $1.373^{* *}$ & $<0.0001+$ & $<0.0001+$ \\
\hline Cupania vernalis & 67 & $1.490^{* * *}$ & $-1.491^{* * *}$ & $1.251^{*}$ & $0.9979-$ & 0.8083 \\
\hline Allophylus edulis & 51 & 1.055 & -1.055 & 0.983 & 0.0532 & $0.0032+$ \\
\hline Myrsine guianensis & 46 & 0.952 & -0.954 & 0.925 & 0.0886 & 0.0697 \\
\hline Cabralea canjerana & 40 & $1.322^{* *}$ & $-1.322^{* *}$ & 1.183 & 0.4245 & 0.5212 \\
\hline Myrsine umbellata & 33 & $1.358^{* *}$ & $-1.355^{\star *}$ & $1.431^{* *}$ & 0.0624 & $0.0176+$ \\
\hline Tetrorchidium rubrivenium & 29 & $1.202 *$ & -1.209 & 1.129 & 0.0701 & $0.0071+$ \\
\hline Trichilia claussenii & 23 & 0.957 & -0.954 & 0.992 & 0.0524 & 0.3865 \\
\hline Diospyros inconstans & 21 & $1.404^{* *}$ & $-1.401^{* *}$ & $1.258^{*}$ & $0.0047+$ & 0.1076 \\
\hline
\end{tabular}

${ }^{*} P<0.1 ;{ }^{* *} P<0.05 ;{ }^{* *} P<0.01 ;(+)=$ significant association; $(-)=$ significant dissociation $; \mathrm{N}=$ density $\left(\right.$ ind.ha $\left.{ }^{-1}\right) ; \mathrm{I}_{\mathrm{a}}=$ index of aggregation; Mvj $=$ average value of $\mathrm{I}_{\mathrm{a}}$ for gaps; $\mathrm{Mvi}=$ average value of $\mathrm{I}_{\mathrm{a}}$ for patches. Spi $\mathrm{x} \mathrm{Spp}=P$ values obtained with association index between spatial distribution of species " $\mathrm{i}$ " (Spi) and spatial distribution of number of species for each sampling unit (Spp); Spi $x$ Nind $=P$ values obtained with association index between spatial distribution of species " $\mathrm{i}$ " and spatial distribution of number of individuals for each sampling unit (Nind).

Table 5. Probability values $(p)$ obtained with association analysis between trees species with at least 20 individual surveyed in a seasonal forest in central region of Rio Grande do Sul, Brazil. Significant association (+) occurs when $p<0.025$ and significant dissociation (-) when $p>0.975$.

\begin{tabular}{|c|c|c|c|c|c|c|c|c|c|c|c|}
\hline & Dio_inc & Tri_cla & Tet_rub & Myr_umb & Cab_can & Myr_gui & All_edu & Cup_ver & Alc_tri & Sor_bon & Nec_meg \\
\hline Cas_syl & 0.1185 & 0.5497 & 0.6473 & 0.0901 & 0.9165 & 0.7495 & $0.0008+$ & 0.3421 & 0.0591 & 0.7008 & 0.8071 \\
\hline Nec_meg & 0.9390 & 0.6773 & 0.1045 & 0.0311 & 0.8453 & 0.8749 & 0.4803 & 0.4358 & 0.0591 & 0.4521 & \\
\hline Sor_bon & 0.8582 & 0.1916 & 0.2284 & 0.8225 & 0.0507 & 0.0758 & 0.8808 & 0.4069 & 0.0331 & & \\
\hline Alc_tri & $0.0014+$ & 0.4462 & 0.2294 & 0.1397 & 0.0606 & $0.0098+$ & 0.2379 & $0.9970-$ & & & \\
\hline Cup_ver & $0.9964-$ & 0.7664 & 0.5698 & 0.5916 & 0.6232 & 0.8779 & 0.1982 & & & & \\
\hline All_edu & 0.1758 & 0.7570 & 0.1435 & 0.0504 & 0.9402 & 0.6372 & & & & & \\
\hline Myr_gui & 0.1750 & 0.4053 & 0.0478 & 0.0937 & $0.0016+$ & & & & & & \\
\hline Cab_can & 0.1499 & 0.0415 & 0.4258 & 0.9534 & & & & & & & \\
\hline$M y r \_u m b$ & 0.1720 & 0.9608 & 0.1891 & & & & & & & & \\
\hline Tet_rub & 0.9274 & 0.9233 & & & & & & & & & \\
\hline Tri_cla & 0.6757 & & & & & & & & & & \\
\hline
\end{tabular}



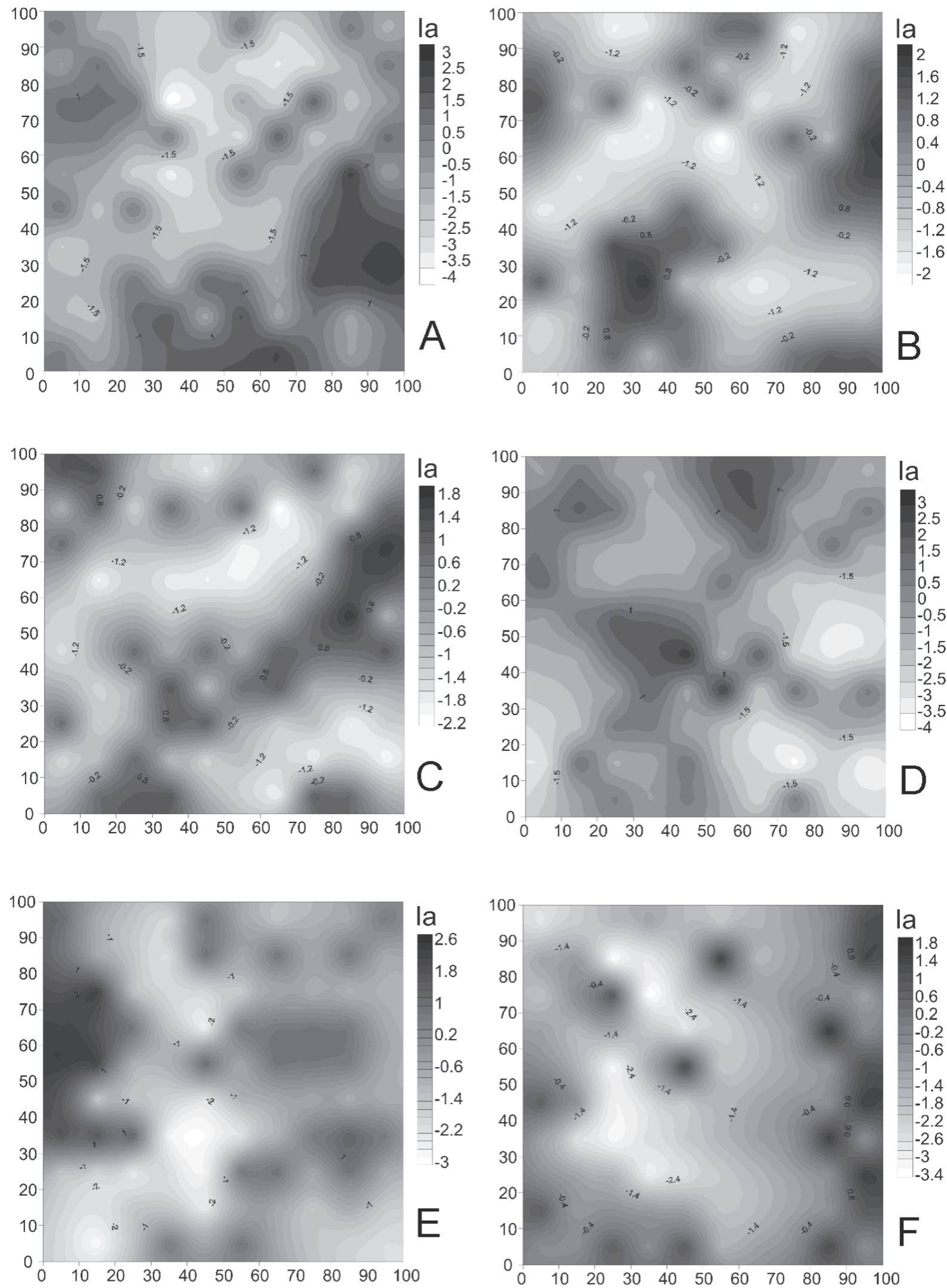

Figure 2. Spatial distribution of Alchornea triplinervia (Spreng.) Müll.Arg. (A), Casearia sylvestris Sw. (B), Allophylus edulis (A.St.-Hil. et al.) Hieron. ex Niederl. (C), Cupania vernalis Cambess. (D), Cabralea canjerana (Vell.) Mart. (E) and Diospyros inconstans Jacq. (F). Ia = aggregation index. 

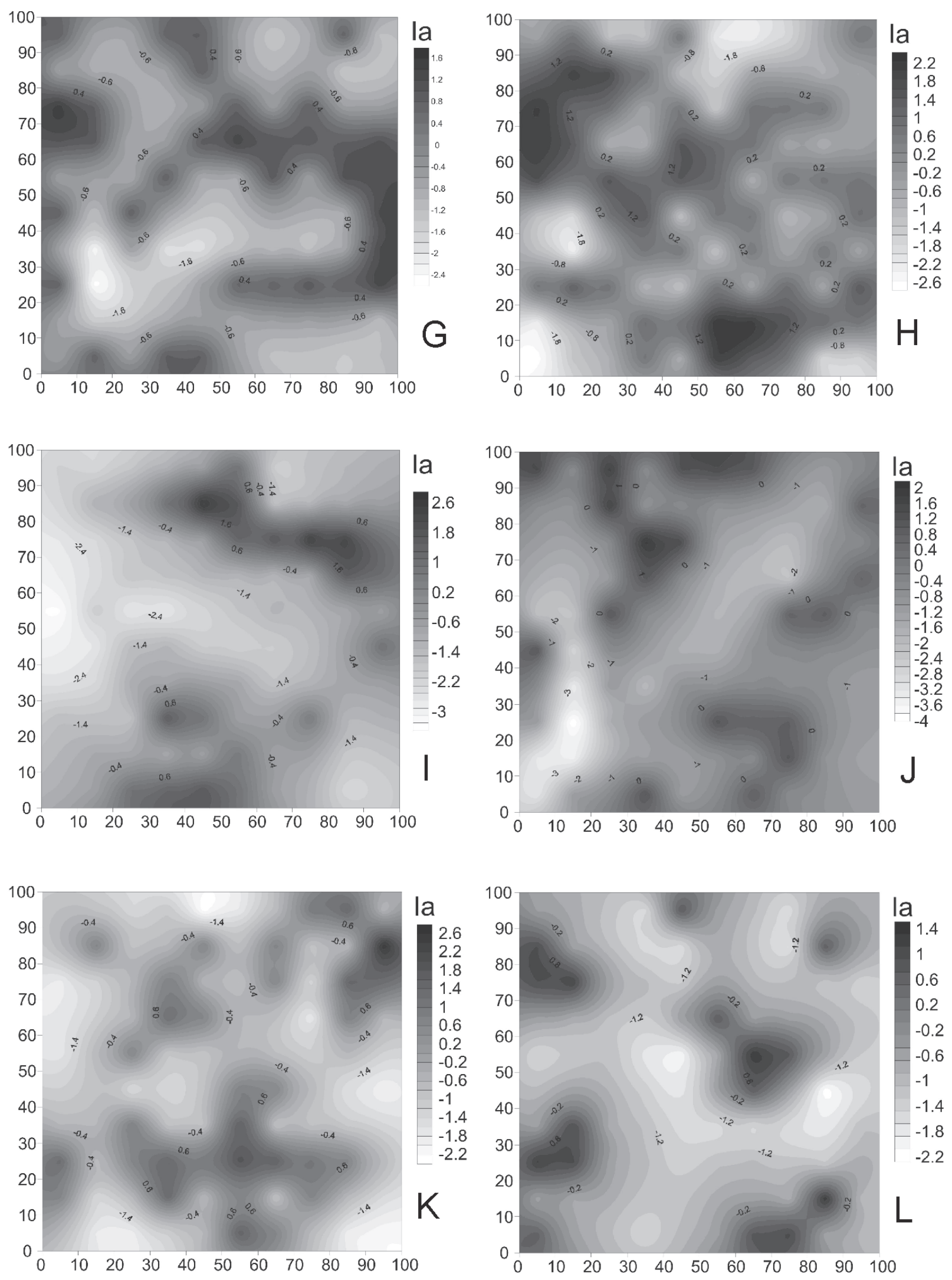

Figure 3. Spatial distribution of Myrsine guianensis (Aubl.) Kuntze (G), Sorocea bonplandii (Baill.) W.C.Burger et al. (H), Myrsine umbellata Mart. (I), Tetrorchidium rubrivenium Poepp. (J), Nectandra megapotamica (Spreng.) Mez (K) and Trichilia claussenii C.DC. (L). Ia = aggregation index. 
there is stand-specific competition between them (Goldberg \& Barton 1992; Devictor et al. 2010) or it had existed at some moment; and IV) both species developed mechanisms to coexist among each other (e.g., creating microsites favorable for coexistence) or among other unknown factors (Christie \& Armesto 2003; Silvertown 2004).

Alchornea triplinervia was associated with seven species (two significant associations and 4 tendencies) and had only one dissociation (significant). Thus, this species also had an association tendency with the spatial distribution of species richness per sampling unit, suggesting that this species occurs in areas with high heterogeneity. The question is why these interactions occur and whether this species itself is the cause of such heterogeneity. The association trends of Alchornea triplinervia with Myrsine umbellata and with Sorocea bonplandii can be emphasized. We can infer that after the last disturbance (e.g. canopy opening by the fall of a large tree), M. umbellata was one of the first tree species which became established, due to its pioneer characteristic (Oliveira et al.2005). Alchornea triplinervia, which is lightdemanding (Rôças et al. 1997) and occupied the highest layer in the present survey, was probably benefited (I) and could establish itself. Finally, S. bonplandii, which is shade tolerant (Budke et al. 2008), could establish itself (I) in the shade provided by A. triplinervia and occupy the lowest layer. At the same time and corroborating this hypothesis, there was a dissociation trend between Myrsine umbellata and Sorocea bonplandii, since their preferences (e.g. regarding luminosity requirements) are different.

Nectandra megapotamica tends to be associated with Alchornea triplinervia and Tetrorchidium rubrivenium. This three species are light-demanding (Vaccaro et al. 1999; Budke et al. 2008) and were large trees in the survey (so they occupied the same stratum). It is still not known if there is some type of facilitation between them (I) or if there is another factor that could benefit them (II), but we can infer that maybe there was (or still there is) competition between them (III) or these species have developed co-existing mechanisms (IV). The same can be inferred to the significant associations that occurred between Casearia sylvestris with Allophylus edulis and Myrsine guianensis with Cabralea canjerana, for example. All of them are lightdemanding species (Budke et al. 2008) and had an average size in the survey, occupying the same stratum.

Cupania vernalis had significant dissociation with the spatial distribution of species richness per sampling unit and tends to be dissociated with the spatial distribution of the number of individuals per sampling unit. Nevertheless, $C$. vernalis was the only species that did not have an association with other species. In a recent study, Gabriel et al. (2007) showed that the young individuals of C. vernalis did not follow the distribution of adults in a forest in southern Brazil. This may be an important strategy of this species and reinforces the hypothesis that it forms dense and dominant groups.
Alpha Diversity and Species Richness - The value of species diversity obtained through the Shannon Index ( $\left.\mathrm{H}^{\prime}\right)$ of 3.35 nats.ind can be considered high when compared to other surveys made on the slopes of the Serra Geral formation. We attribute this elevated value to natural disturbances in the location: I) due to the terrain's inclination and soil characteristics, the two gullies in the studied area probably interfered in the dominance of one species, and II) these gullies provide a permanent canopy gap, which favored the establishment of widely distributed pioneer or lightdemanding species with low density values. The influence and functioning of these disturbances in the richness of tropical and subtropical forests, has been demonstrated in current studies (Schintzer \& Carson 2001; Sheil \& Burslem 2003; Smith et al. 2005). These disturbances play an important role in the structure of plant communities, leading to environmental heterogeneity in time and space at different scales (Budke et al. 2010).

A reduction of species richness can be seen from east to west when comparing the farthest east survey, located in the tropical rain forest domain, with our survey and with the farthest west survey, both located in the seasonal forest domain. The latter had $40 \%$ less species than the farthest east one. However, the correlation analysis done with the total amount of species of each survey showed that there is not a clear reduction of species richness from east to west because some of the compared surveys showed an oscillation in their richness values, so that the reduction line from east to west was not rectilinear. This fact can be related to local factors and not regional, because canopy gaps, big tree falls, or other local disturbances may create microsites which influence species richness and forest structure (Christie \& Armesto 2003; Smith et al. 2005; Budke et al. 2010). It is also worth noting that two surveys, despite being in relatively close longitudes (e.g., our survey and the survey done in Vale do Sol), may have differences in their richness due to the elevation factor (Budke et al. 2004). From this premise, the present survey (done at 500 m.s.l.) had less species from the east contingent and also more species from the west contingent than the survey located in Vale do Sol (done at 100-140 m.s.l.), which is located a few kilometers to the west. So we considered that the survey of Vale do Sol had more characteristics from the east contingent than the present one.

After partitioning the amount of species of each floristic contingent (western seasonal, eastern wet and wide geographical distribution) for each survey, a pattern became clear with the correlation analysis: at the same time that a reduction of the eastern wet species from east to west occurs, there is an increase of western seasonal species in the same direction. From this, we can infer that beyond a species reduction process there is a replacing process of the Atlantic species to seasonal tree species towards the west. 


\section{Acknowledgements}

We sincerely thank Joe Perry, Kelvin Conrad, Nicholas Gotelli and Rob Brooker for suggestions.

\section{References}

Anjos, A.; Mazza, M.C.M.; Santos A.C.M. \& Delfini, L.T. 2004. Análise do padrão de distribuição espacial da araucária (Araucaria angustifolia) em algumas áreas no Estado do Paraná, utilizando a função $\mathrm{K}$ de Ripley. Scientia Forestalis 66: 38-45.

APG III. 2009. An update of the Angiosperm Phylogeny Group classification for the orders and families of flowering plants. Botanical Journal of the Linnean Society 161: 105-121.

Bell, J.R.; King, R.A.; Bohan, D.A. \& Symondson, W.O.C. 2010. Spatial co-occurrence networks predict the feeding histories of polyphagous arthropod predators at field scales. Ecography 33: 1-9.

Brasil. 2009. Ministério do Meio Ambiente. Portaria No 16, de 18 de Março 2009. Diário Oficial da União, seção 1, n. 53.

Brooker, R.W.; Maestre, F.T.; Callaway, R.M.; Lortie, C.L.; Cavieres, L.A.; Kunstler, G.; Liancourt, P.; Tielbörger, K.; Travis, J.M.J.; Anthelme, F.; Armas, C.; Coll, L.; Corcket, E.; Delzon, S.; Forey, E.; Kikvidze, Z.; Olofsson, J.; Pugnaire, F.; Quiroz, C.L.; Saccone, P.; Schiffers, K.; Seifan, M.; Touzard, B. \& Michalet, R. 2008. Facilitation in plant communities: the past, the present, and the future. Journal of Ecology 96: 18-34.

Budke, J.C.; Giehl, E.L.H.; Athayde, E.A.A.; Eisinger, S.M. \& Záchia, R.A. 2004. Florística e fitossociologia do componente arbóreo de uma floresta ribeirinha, arroio Passo das Tropas, Santa Maria, RS, Brasil. Acta Botanica Brasilica 18: 581-589.

Budke, J.C.; Jarenkow, J.A. \& Oliveira-Filho, A.T. 2008. Tree community features of two stands of riverine forest under different flooding regimes in Southern Brazil. Flora 203: 162-174.

Budke, J.C.; Jarenkow, J.A. \& Oliveira-Filho, A.T. 2010. Intermediary disturbance increases tree diversity in riverine forest of southern Brazil. Biodiversity and Conservation 19: 2371-2387.

Christie, D.A. \& Armesto, J.J. 2003. Regeneration microsites and tree species coexistence in temperate rain forests of Chiloé Island, Chile. Journal of Ecology 91: 776-784.

Comissão de Química e Fertilidade do Solo. 2004. Manual de adubação e de calagem para os estados do RS e SC. Porto Alegre, Sociedade Brasileira de Ciência do Solo - Núcleo Regional Sul.

Conrad, K.F.; Perry, J.N.; Woiwod, I.P. \& Alexander, C.J. 2006. Large-scale temporal changes in spatial pattern during declines of abundance and occupancy in a common moth. Journal of Insect Conservation 10: 53-64.

Dale, M.R.T.; Dixon, P.; Fortin, M.J.; Legendre, P.; Myers, D.E. \& Rosenberg, M.S. 2002. Conceptual and mathematical relationships among methods for spatial analysis. Ecography 25: 558-577.

Devictor, V.; Clavel, J.; Julliard, R.; Lavergne, S.; Mouillot, D.; Thuiller, W.; Venail, P.; Villérger, S. \& Mouquet, N. 2010. Defining and measuring ecological specialization. Journal of Applied Ecology 47: 15-25.

Donovan, S.E.; Griffiths, G.J.K.; Homathevi, R. \& Winder, L. 2007. The spatial pattern of soil-dwelling termites in primary and logged forest in Sabah, Malaysia. Ecological Entomology 32: 1-10.

Ferguson, A.W.; Klukowski, Z.; Walczak, B.; Perry, J.N.; Mugglestone, M.A.; Clark, S.J. \& Williams, I.H. 2000. The spatio-temporal distribution of adult Ceutorhynchus assimilis in a crop of winter oilseed rape in relation to the distribution of their larvae and that of the parasitoid Trichomalus perfectus. Entomologia Experimentalis et Applicatta 95: 161-171.

Forzza, R.C.; Leitman, P.M.; Costa, A.F.; Carvalho Jr., A.A.; Peixoto, A.L.; Walter, B.M.T.; Bicudo, C.; Zappi, D.; Costa, D.P.; Lleras, E.; Martinelli, G.; Lima, H.C.; Prado, J.; Stehmann, J.R.; Baumgratz, J.F.A.; Pirani, J.R.; Sylvestre, L.; Maia, L.C.; Lohmann, L.G.; Queiroz, L.P.; Silveira, M.; Coelho, M.N.; Mamede, M.C.; Bastos, M.N.C.; Morim, M.P.; Barbosa, M.R.; Menezes, M.; Hopkins, M.; Secco, R.; Cavalcanti, T.B.; Souza, V.C. 2010. Introdução. Lista de Espécies da Flora do Brasil. Jardim
Botânico do Rio de Janeiro. Disponível em http://floradobrasil.jbrj. gov.br/2010/ (Acesso em 09/11/10).

Franklin, J. \& Rey, S.J. 2007. Spatial patterns of tropical forest trees in Western Polynesia suggest recruitment limitations during secondary succession. Journal of Tropical Ecology 23: 1-12.

Gabriel, C.; Azambuja, B.O.; Giehl, E.L.H. \& Eisinger, S.M. 2007. Revista Brasileira de Biociências 5: 624-626.

Giehl, E.L.H.; Athayde, E.A.; Budke, J.C.; Gesing, J.P.A.; Eisinger, S.M. \& Canto-Dorow, T.S. 2007. Espectro e distribuição vertical das estratégias de dispersão de diásporos do componente arbóreo em uma floresta estacional no sul do Brasil. Acta Botanica Brasilica 21: 137-145.

Giehl, E.L.H. \& Budke, J.C. 2011. Aplicação do método científico em estudos fitossociológicos no Brasil: em busca de um paradigma. Pp. 1-21. In: Felfili, J.M.; Eisenlohr, P.V.; Melo, M.M.R.F. Andrade, L.A.; Meira Neto J.A.A. (Org.). Fitossociologia no Brasil: métodos e estudos de caso. UFV: Viçosa, Sociedade Botânica do Brasil.

Goldberg, D.E. \& Barton, A.M. 1992. Patterns and consequences of interspecific competition in natural communities: a review of field experiments with plants. The American Naturalist 139: 771-801.

Hammer, Ø.; Harper, D.A.T \& Ryan, P.D. 2001. PAST: Paleontological statistics software package for education and data analysis. Palaeontologia Electronica 4.

Higuchi, P.; Silva, A.C.; Louzada, J.N.C. \& Machado, E.L.M. 2010. Spatial patterns of a tropical tree species growing under an eucalyptus plantation in South-East Brazil. Brazilian Journal of Biology 70: 271-277.

Hooten, M.B.; Larsen, D.R. \& Wikle, C.K. 2003. Predicting the spatial distribution of ground flora on large domains using a hierarchical Bayesian model. Landscape Ecology 18: 487-502.

Jarenkow, J.A. 1994. Estudo fitossociológico comparativo entre duas áreas com mata de encosta no Rio Grande do Sul. São Carlos, UFSCar. Tese de Doutorado, Centro de Ciências e da Saúde, Universidade Federal de São Carlos.

Jarenkow, J.A. \& Waechter, J.L. 2001. Composição, estrutura e relações florísticas do componente arbóreo de uma floresta estacional no Rio Grande do Sul, Brasil. Revista Brasileira de Botânica 24: 263-272.

Jarenkow, J.A. \& Budke, J.C. 2009. Padrões florísticos e análise estrutural de remanescentes florestais com Araucaria angustifolia no Brasil. Pp. 113-126. In: Fonseca, C.S.D.; Souza, A.F.; Zanchet, A.M.L.; Dutra, T.; Backes, A.; Ganade, G.M.S. (Org.). Floresta com Araucária: ecologia, conservação e desenvolvimento sustentável. Ribeirão Preto, Holos.

Jurinitz, C.F. \& Jarenkow, J.A. 2003. Estrutura do componente arbóreo de uma floresta estacional na Serra do Sudeste, Rio Grande do Sul, Brasil. Revista Brasileira de Botânica 26: 475-487.

Koellner, T.; Hersperger, A.M. \& Wohlgemuth, T. 2004. Rarefaction method for assessing plant species diversity on a regional scale. Ecography 27: 532-544.

Legendre, P. \& Fortin, M.J. 1989. Spatial pattern and ecological analysis. Vegetatio 80: 107-138.

Levine, J. 1999. Indirect facilitation: evidence and predictions from a riparian community. Ecology 80: 1762-1769.

Lindenmaier, D.S. \& Budke, J.C. 2006. Florística, diversidade e distribuição espacial das espécies arbóreas em uma floresta estacional na bacia do Rio Jacuí, sul do Brasil. Pesquisas, Botânica 57: 193-216.

Longhi, S.J.; Nascimento, A.R.T.; Fleig F.D.; Della-Flora, J.B.; Freitas, R.A. \& Charão, L.W. 1999. Composição florística e estrutura da comunidade arbórea de um fragmento florestal no município de Santa Maria-Brasil. Ciência Florestal 9: 115-133.

Longhi, S.J.; Araujo, M.M.; Kelling, M.B.; Hoppe, J.M.; Müller, I. \& Borsoi, G.A. 2000. Aspectos fitossociológicos de fragmento de floresta estacional decidual, Santa Maria, RS. Ciência Florestal 10: 59-74.

Maluf, J.R.T. 2000. Nova classificação climática do Rio Grande do Sul. Revista Brasileira de Agrometeorologia 8: 141-150.

Muller-Dombois, D. \& Ellenberg, H. 1974. Aims and methods of vegetation ecology. New York, Wiley.

Nascimento, N.A.; Carvalho, J.O.P. \& Leão, N.V.M. 2002. Distribuição espacial de espécies arbóreas relacionada ao manejo de Florestas Naturais. Revista Ciência Agrária 37: 175-194. 
Oliveira, M. de L.A.A.; Balbueno, R.A. \& Senna, R.M. 2005. Levantamento florístico de fragmentos florestais na bacia hidrográfica do rio Gravataí, Rio Grande do Sul, Brasil Iheringia, Série Botânica 60: 269-284

Paludo, G.F.; Mantovani, A.; Klauberg, C. \& Reis, M.S. 2009. Estrutura demográfica e padrão espacial de uma população natural de Araucaria angustifolia (Bertol.) Kuntze (Araucariaceae), na Reserva Genética Florestal de Caçador, Estado de Santa Catarina. Revista Árvore 33: 1109-1121.

Pélissier, R. 1998. Tree spatial patterns in three contrasting plots of a southern Indian tropical moist evergreen forest. Journal of Tropical Ecology 14: 1-16.

Perry, J.N. 1995. Spatial analysis by distance indices. Journal of Animal Ecology 64: 303-314.

Perry, J.N.; Bell, E.D.; Smith, R.H. \& Woiwoid, I.P. 1996. SADIE: software to measure and model spatial pattern. Aspects of Applied Biology 46: $95-102$.

Perry, J.N. 1998. Measures of spatial pattern for counts. Ecology 79: 1008-1017.

Perry, J.N.; Winder, L.; Holland, J.M. \& Alston, R.D. 1999. Red-blue plots for detecting clusters in count data. Ecology Letters 2: 106-113.

Perry, J.N. \& Dixon 2002. A new method for measuring spatial association in ecological count data. Ecoscience 9: 133-141.

Perry, J.N.; Liebhold, A.M.; Rosenberg, M.S.; Dungan, J.; Miriti, M.; Jakomulska, A. \& Citron-Pousty, S. 2002. Illustrations and guidelines for selecting statistical methods for quantifying spatial pattern in ecological data. Ecography 25: 578-600.

Rambo, B. 1956. A fisionomia do Rio Grande do Sul. 2. ed. Porto Alegre, Selbach.

Rambo, B. 1960. Die Südgrenze des brasilianischen Regenwaldes. Pesquisas, Botânica 8: 5-41.

Rambo, B. 1961. Migration routes of the South Brazilian rain Forest. Pesquisas, Botânica 12: 1-54.

Rechenmacher, C.; Schmitt, J.L. \& Budke, J.C. 2007. Estrutura e distribuição espacial de uma população de Blechnum tabulare (thunb.) Kuhn (Pteridophyta, Blechnaceae) em um mosaico floresta-campo no sul do Brasil. Pesquisas, Botânica 58: 177-186.

Rôças, G.; Barros, C.F. \& Scarano, F.R. 1997. Alchornea triplinervia (Euphorbiaceae) under distinct light regimes in a Brazilian montane Atlantic rain forest. Trees 11: 469-473.

Rode, R.; Figueiredo-Filho, A.; Machado, S.A. \& Galvão, F. 2010. Análise do padrão espacial de espécies e de grupos florísticos estabelecidos em um povoamento de Araucaria angustifolia e em uma Floresta Ombrófila Mista no centro-sul do Paraná. Floresta 40: 255-268.

Schnitzer, S.A. \& Carson, W.P. 2001. Treefall gaps and the maintenance of species diversity in a tropical forest. Ecology 82: 913-919.

Sheil, D. \& Burslem, D.F.R.P. 2003. Disturbing hypotheses in tropical forests. Trends in Ecology \& Evolution 18: 18-26.

Silvertown, J. 2004. Plant coexistence and the niche. Trends in Ecology and Evolution 19: 605-611.

Smith, R.G.B.; Nichols, J.D. \& Vanclay, J.K. 2005. Dynamics of tree diversity in undisturbed and logged subtropical rainforest in Australia. Biodiversity and Conservation 14: 2447-2463.

Smith, A.R.; Pryer, K.M.; Schuettpelz, E.; Korall, P.; Schneider, H. \& Wolf, P.G. 2006. A classification for extant ferns. Taxon 55: 705-731.

Sonego, R.C.; Backes, A. \& Souza, A.F. 2007. Descrição da estrutura de uma Floresta Ombrófila Mista, RS, Brasil, utilizando estimadores não paramétricos de riqueza e rarefação de amostras. Brasília, Acta Botanica Brasilica 21: 943-955.

Streck, E.V.; Kämpf, N.; Dalmolin, R.S.D.; Klamt, E.; Nascimento, P.C. \& Schneider, P. 2002. Solos do Rio Grande do Sul.

Sühs, R.B.; Putzke, J. \& Budke, J.C. 2010. Relações florístico-geográficas de espécies arbóreas em remanescente florestal da região central do Rio Grande do Sul, Brasil. Revista Floresta 40: 635-646.

Teixeira, M.B.; Coura-Neto, A.B.; Pastore, U. \& Rangel-Filho, A.L.R. 1986. Vegetação In: Levantamento de recursos naturais 33: 541-632. Instituto Brasileiro de Geografia e Estatística.

Vaccaro, S.; Longhi, S.J. \& Brena, D.A. 1999. Aspectos da composição florística e categorias sucessionais do estrato arbóreo de três subseres de uma floresta Estacional Decidual, no município de Santa Tereza RS. Ciência Florestal 9: 1-18.

$\mathrm{Xu}, \mathrm{X} .-\mathrm{M} .2003$. Considerations for the use of SADIE statistics to quantify spatial patterns. Ecography 26: 821-830.

Xu, X.-M. \& Madden, L.M. Use of SADIE statistics to study spatial dynamics of plant disease epidemics. 2004. Plant Pathology 53: 38-49.

Waite, S. 2000. Statistical Ecology in Practice: A Guide to Analysing Environmental and Ecological Field Data. Essex, Pearson Education Ltd.

Winder, L.; Alexander, C.J.; Holland, J.M.; Wooley, C. \& Perry, J.N. 2001. Modelling the dynamic spatio-temporal response of predators to transient prey patches in the field. Ecology Letters 4: $568-576$. 